\title{
THE DUTY AND LIABILITY OF BANK DIRECTORS.*
}

I. As directors owe their official existence to positive law or statute, so by statute are their duties and liabilities defined and enforced. But when their conduct is fraudulent, they are liable, regardless of any statute, primarily to the bank, ${ }^{1}$ and secondarily to its creditors, whom they have defrauded. In many States also they are liable to the bank, its stockholders and creditors for negligence so great that it cannot be overlooked or excused even though

\section{*.ANALYSIS.}

I. Liability of Directors at Common Law.

II. Difficulty in prescribing Rules of Duty and Liability.

III. Rule of Ordinary Care.

IV. Rule of Prudence.

V. These Rules regard their Liability from Different Points of View.

VI. Comparative Local Rule.

VII. Elimination of Four Classes of Cases. Fraud.

VIII. Mistakes.

IX. Specific Violations of Statute.

$X$. Wrongful or Neglectful Exercise of Authority.

XI. Application of the Law in above Classes of Cases.

XII. They are Cases of Super-Negligence.

XIII. Only Cases of Real Negligence are left for consideration.

XIV. Application of the two Rules of Duty and Liability to these Cases.

XV. Narrowing of Director's Responsibility.

XVI. Duty and Liability of Non-Resident and Absent Directors.

XVII. Directors Primarily Wrong their Bank. When Stockholders can sue.

XVIII. If Insolvent, Receiver or Assignee can sue.

XIX. If he will not, Stockholders can sue.

XX. When Creditors can sue.

${ }^{1}$ Vose v. Grant, I5 Mass. 505, 519; Smith r. Hurd, I2 Met. (Mass.) 37I; Bartholomew v. Bentley, I5 Ohio 659: Smith v. Poor, 40 Me. 415; Allen v. Curtis. 26 Conn. 460 ; Winter v. Baker, 34 How. Pr. (N. Y.) I83: Watts's Appeal, $78 \mathrm{~Pa}$. 370: Warren v. Hopkins, III Pa. 328; Zinn v. Mendel. $9 \mathrm{WI}$. Va. 580; Minton v. Stahlman, 96 Tenn. 98; Deadrick v. Bank. I00 Tenn. 457; Gores v. Day, 99 Wis. 276, 278.

${ }^{2}$ Deadrick v. Bank, Ion Tenn. 457: Minton v. Stahlman, 96 Tenn. 98; Duffy v. Byrne. 7 Mo. App. 417; Fusz v. Spaunhorst, 67 Mo. 256; Gores v. Day, 99 Wis. 276. 
untainted with fraud. In other States, however, a distinction is drawn between fraudulent and non-fraudulent misconduct; and in the latter class of cases they are liable to the bank alone, and not to its creditors. ${ }^{2}$ This distinction must be noted at the outset, while the soundness of it is reserved for later consideration. ${ }^{3}$

II. The general rule of duty governing directors cannot be expressed in a rigid form. In the earlier days, when business methods were slower and simpler, the law maintained in a fairly satisfactory manner boundaries in the care which individuals were required to exercise while pursuing, under different conditions, their office or employment. But business methods have become so complex that many of these boundaries are disappearing. Between employers and employés, however, the courts are still spinning their distinctions concerning duty and liability with ever-increasing fineness, and thus enhancing the difficulty of both classes to know the law which they are required to observe.

Though the courts no longer seek to measure the differences in care by the old-fashioned rules of slight, ordinary and great, it is difficult in comparing one act with another to avoid altogether the use of these qualifying terms. One board of directors is more attentive, more dutiful than another; and when their conduct is compared, some words expressing the distinctions between them must be used so long as these exist.

There are two ways of regarding the duty, care or attention required of a board of directors. One way is to set up an abstract standard or rule and apply this to the board of a particular bank, whose conduct is the subject of legal inquiry. The other way is to compare their conduct with that of another board which fulfills the legal requirements. The law employs both methods; with what results we shall soon know.

III. Two abstract rules have long competed for judicial approval and application. The first of these was declared in I829. by the Supreme Court of Louisiana, in Percy v. Millaudon,-the earliest case of bank misdirection reviewed by a court in this country. "The only correct mode of ascertaining whethet there was fault in the director," says Justice Porter," who delivered the opinion of

${ }^{1}$ Brinckerhoff v. Bostwick, 88 N. Y. 52 . See Secs. I7-20.

2Minton v. Stahlman, 96 Tenn. 98; Deadrick v. Bank, 100 Tenn. 457.

${ }^{3}$ See Sec. 20.

18 Martin (N. S.) 68, 73; Godbold v. Branch Bank, II Ala. I9I ; Spering's. Appeal, 7 I Pa. Ir. 
the court, "is by inquiring whether he neglected the exercise of that diligence and care which was necessary to a successful discharge of the duty imposed on him. That diligence and care must again depend on the nature of the undertaking. There are many things which, in their management, require the utmost diligence, and most scrupulous attention, and where the agent who undertakes their direction renders himself responsible for the slightest neglect. There are others, where the duties imposed are presumed to call for nothing more than ordinary care and attention, and where the exercise of that degree of care suffices. The directors of banks from the nature of their undertaking fall within the class last mentioned, while in the discharge of their ordinary duties."

IV. By the other rule directors must exercise the same degree of attention in conducting the business of their bank that is exercised by prudent men in conducting their own affairs. In a recent well-considered case the court thus stated the principle:" "It is necessary for them to give the business under their care such attention as an ordinarily discreet business man would give to his own concerns under similar circumstances, and it is therefore incumbent upon them to devote so much of their time to their trust as is necessary to familiarize them with the business of the institution and to supervise and direct its operations."

V. The two rules regard the duty and liability of directors from different points of view. The first, or minimum liability rule, regards the matter from the director's side. $\mathrm{He}$ is indeed required to exercise a general supervision, and fulfill a few specific statutory requirements, but not much more. It is not expected that he will devote much time to the affairs of the bank, as he is rarely paid anything for his service, and generally is engaged in other and far more important business. It is not reasonable to expect that he will examine the books and other records, and without doing these things he cannot know much about the details of the bank's affairs;

1. Bartch, Ch. J., Warren v. Robison, I9 Utah 289, 303.

"I think the question in all such cases should and must necessarily be, whether the directors have omitted that care which men of common prudence take of their own concerns. To require more, would be adopting too rigid a rule, and rendering them liable for slight neglect; while to require less would be relaxing too much the obligation which binds them to vigilance and attention in regard to the interests of those confided to their care, and expose them to liability for gross neglect only-which is very little short of fraud itself." Vice Chancellor McCoun. Scott v. Depeyster, I Edw. Ch. (N. Y.) 513,543 . 
and this is supposed to be known by all who do business with banking institutions.

The other rule regards the duty and liability of directors from the public side. This view is forcibly expressed by Justice Earl, in these words: "It seems to me that it would be a monstrous proposition to hold that trustees, intrusted with the management of the property, interests and business of other people, who divest themselves of the management and confide in them, are bound to give only slight care to the duties of their trust, and are liable only in case of gross inattention and negligence; and $I$ have found no authority fully upholding such a proposition. It is true that authorities are found which hold that trustees are liable only for crassa negligentia, which literally means gross negligence; but that phrase has been defined to mean the absence of ordinary care and diligence adequate to the particular case. *** Like a mandatary, to whom he has been likened, he is bound not only to exercise proper care and diligence, but ordinary skill and judgment. *** These defendants voluntarily took the position of trustees of the bank. They invited depositors to confide to them their savings, and to intrust the safe-keeping and management of them to their skill and prudence. They undertook not only that they would discharge their duties with proper care, but that they would exercise the ordinary skill and judgment requisite for the discharge of their delicate trust." 1

Doubtless every court looks from both sides; but it is just as certain that its judgment is often deflected from the rules to the inculpated directors. The evidence against them is examined, an opinion is formed of their guilt or innocence, and then a color or modification, if necessary, is given to the rule, to fit it properly to the facts. The numerous penumbra that surround the rules above given are unquestionable proof of the working of the judicial mind in these controversies.

VI. The other rule may be called the comparative one, and will be stated in the words of Chief Justice Paxson:" "Not the ordinary

1 Hun v. Cary, 82 N. Y. $65,72,73$. This statement of the maximum rule has been more often quoted with approval than any other legal deliverance.

2Swentzel v. Penn Bank, I47 Pa. I40.

In Wheeler v. Aiken Co. Loan \& Sav. Bank, 75 Fed. 78I, 784, Judge Brawley said: "The customs and methods of the community in which the business is done are, for such community, a standard of prudence and diligence by which the responsibility of bank officers and directors is to be tested; and if there is ground to believe that there has been a reasonable 
care which a man takes of his own business, but the ordinary care of a bank director in the business of a bank. Negligence is the want of care according to the circumstances, and the circumstances are everything considering the question."

By this rule the directorial standard of duty is the standard existing among the directors of other banks in the same city. In another part of his opinion the Justice remarked: "If the director [on trial] performed his duties as such in the same manner as they were performed by all other directors of all other banks in the same city, it could not be fairly said that he was guilty of gross negligence."

The flaw in this rule is apparent. What board in a great city is to serve as the measure or standard whereby to test the conduct of a director? In every large city the boards differ greatly in their interest, attendance, methods and efficiency. In a few banks the attendance of their directors is large and regular, and a keen interest is taken by them in all its affairs. Perhaps they are large stockholders, and are fully impressed with the duties and liabilities of their office. In other banks the interest is slight, the attendance small and irregular, and the business, except a few statutory requirements, is entrusted to the managing officers.

This rule, therefore, as thus expressed, is singularly indefinite. If Justice Paxson had said that the standard to be applied to a director is that of the bank or banks whose directors take the deepest interest and devote the most attention to their management, then indeed the standard or measure would be definite and could be learned and applied. But since the directors in a large city vary so greatly in their interest, attendance and attention, the above standard of duty means very little, if anything, either in theory or application.

VII. Having described the rules that apply to the conduct of directors, the next step is to show how they have been applied. The storm-center can be more easily reached by cutting off four large classes of cases in which judicial decision has been essentially harmonious.

The first class includes all cases in which the conduct of directors is inipregnated with fraud or bad faith. Fraud may have several

conformity i: such methods and customs. and absolute good faith and lionẹsty of purpose, it would be unjust to hold to a personal accountability for loans which subsequent crents proved unwise." Judge Brawley goes further than Justice Paxson for he adds to the local standard of conduct, "absolute good faith and honesty of purpose." 
forms, active and passive, open and secret. If a director is wantonly defrauding his bank there is no question concerning his liability. In a larger number of cases it assumes a less obvious form. Many men are of a pacific temperament and dislike to quarrel; they suffer physically and mentally by conflict. Then, too, for business reasons they may fear to incur the enmity of their associates; and are silent and inactives when they should be outspoken and vigilant in the discharge of their duty. So long as they are inattentive because their own business demands their time, they are not deemed neglectful; indeed, if their inattention is due simply to inertia, or disinclination to attend board meetings they are not regarded as within the fatal range of liability. In like manner when they travel abroad and for months do not meet with their associates the law does not visit them with any penalty for their non-attendance. ${ }^{1}$

When, however, they keep silent or remain away because they suspect or fear that the conduct of their bank is not proper, instead of coming and seeking to correct the board, then they incur the displeasure of the law; become in truth passive participants in the wrong doing. So long as they honestly believe their associates are doing their duty, absentees cannot be holden on that ground although, if they had come, they might have speedily unlearned their delusion. There is no smell of fraud on their garments so long as they have no wrongful suspicions. But the poison begins to work as soon as they suspect, fear or learn that the directors are doing wrong and they preserve silence or remain away to escape learning more. In other words, as soon as a belief, fear or suspicion arises in their minds, it is their duty to become active and make an investigation to find out the truth or falsity of it; and if there be any foundation therefor, to strive for its correction, and, if failing, to resign. Not to do this is to become in law a participant in the fraud, and justly liable therefor. ${ }^{2}$

${ }^{1}$ See Sec. I6.

2Says Porter, J., in Percy v. Millaudon, 8 Martin (La., N. S.) 63, 65: "If nothing has come to their knowledge to awaken suspicion of the fidelity of the president and cashier, ordinary attention to the affairs of the institution is sufficient. If they become acquainted with any part calculated to put prudent men on their guard, a degree of care commensurate with the evil to be avoided is required, and a want of that care certainly makes them responsible." See Briggs v. Spaulding, I4I U. S. 132.

In Martin v. Webb, rro U. S. 15, the court said: "Directors cannot in justice to those who deal with the bank, shut their eyes to what is going on around them. It is their duty to use ordinary diligence in ascertaining 
VIII. Another approach toward the center may be made from the opposite side. Directors who seek to do their duty are not responsible for mistakes of law or fact. ${ }^{1}$ If before employing a cashier they investigate his fitness, mental and moral, and are satisfied that he is competent, they are not responsible should he prove to be otherwise. But if, after discovering his incompetency, or unfitness, they continue him in office, unless temporarily while trying to find another, they are liable for the consequences. ${ }^{2}$

the condition of its business, and to exercise reasonable control and supervision of its officers."

In Clews v. Bardon, 36 Fed. 617, 621, Bunn, J., said: "The [national] banking act places their liability upon the true ground, and it stands about as it would in the like circumstances at the common law. In either case the director is bound to good faith. He must act honestly. He must not commit fraud, nor be privy to it, nor willfully shut his eyes, and abstain from making inquiries. If he has knowledge that an illegal transaction is to be enacted by the officers in charge, and consents to it, or connives at it, or willfully shuts his eyes, and permits it to be done, or is guilty of such gross and willful neglect of duty as amounts to bad faith, he will be held responsible."

For cases in which this rule has been applied or declared, see Godbold v. Bank, II Ala. Igt; Bank of St. Marys v. St. John, 25 Ala. 566; Schley v. Dixon, $24 \mathrm{Ga}$. 275; Dunn v. Kyle, I4 Bush (Ky.) I34; Brannin v. Loving, 82 Ky. 370; Fusz v. Spaunhorst, 67 Mo. 256; Delano v. Case, 121 Ill. 247; Robinson v. Smith, 3 Paige (N. Y.) 222; Brinckerhoff v. Bostwick, 88 N. Y. 52; Cross v. Sackett, 2 Bos. (N. Y.) 617, 645; Spering's Appeal. 7I Pa. II ; Marshall v. Farmers \& Mechanics' Sav. Bank, 85 Va. 676; Minton v. Stahlman, 96 Tenn. 98; Bartholomew v. Bentley, I5 Ohio 659; Seale v. Baker, 70 Texas 283; Solomon v. Bates, II8 N. C. 3II; Tate v. Bates, II8 N. C. 287 ; Briggs v. Spaulding, I4I U. S. 132; Robinson v. Hall, 12 C. C. A. 674; Cooper v. Hill, 36 C. C. A. 402 ; Prescott v. Haughey, 65 Fed. 653.

${ }^{1}$ Godbold v. Bank, II Ala. I9I; Smith v. Prattville Mfg. Co., 29 Ala. 503; United Society of Shakers v. Underwood, 9 Bush (Ky.) I; Graves v. Lebanon Nat. Bank, to Bush (Ky.) 23; Dunn v. Kyle, 14 Bush (Ky.) 134; Ray v. Bank, to Bush (Ky.) 344; Savings Bank v. Caperton, $87 \mathrm{Ky}$. 306; Jones v. Johnson, $86 \mathrm{Ky}$. 530; Percy v. Millaudon, 8 Martin (La., N. S.) 68; Vance v. Phoenix Ins. Co., 4 Lea (Tenn.) 385; Wallace v. Lincoln Sav. Bank, 89 Tenn. 630: Foster v. Essex Bank, I7 Mass. 479; Ackerman v. Halsey, 37 N. J. Eq. 356, 363; Hodges v. New England Screw Co.. I R. I. 312: Scott v. Depeyster, I Edw. Ch. (N. Y.) 513; Manhattan Co. v. Lydig. 4 Johns. (N. Y.) 377; Marshall v. Farmers \& Mechanics' Sav. Bank. 85 Va. 676; Solomon v. Bates. II8 N. C. 3II: Turquand $r$. Marshall, 4 Cl. App. 376. 386; Overend, Gurney \& Co. v. Gurney, + Ch. App. 7or; Giblin v. McMullen, 2 P. C. 3I7; Spering's Appeal. 7I Pa. II.

'United Society of Shakers v. Linderwood. a Bush (Ky.) 6on; Ray v. Bank, ro Bush 344; Graves v. Lebanon Nat. Bank, 1o Bush 23. 30; Foster v. Essex Bank, 17 Mass. 479; Scott v. National Bank of Chester Valley, $72 \mathrm{~Pa}$. 471; Giblin v. McMullen, 2 P. C. 317. 
Again, if they make mistakes in lending money and incur losses, after exercising their best judgment, they are not liable, ${ }^{1}$ nor are they for legal mistakes, ${ }^{2}$ especially when they have sought competent advice.

In this category may be placed a large number of delinquencies of a minor kind that do not affect their integrity or injure the bank, which are not in any way vital to its successful operation, for example, the failure, through inattention and not design, to make reports, or reports less complete than the law requires.

IX. A third class of cases may be cut off, specific violations of positive law. The conduct of directors on many of these occasions is without a stain of fraud, but they are just as clearly liable for knowingly and deliberately violating a clear, positive law whereby others, confiding in their honesty and loyalty, have suffered.

Thus in nearly every State usury laws exist which limit the discretion of banks in lending money. The directors, for the sake of enhancing the gains of their bank, determine to disregard the inhibition. They commit no moral fraud, and have not the slightest intention of so doing; the law, standing in the way of greater profit, is openly defied. A higher rate is charged, but a greater risk is taken, and the loan proves a loss. Had they obeyed the law and been content with the legal rate, they would have found better security, at all events they would have been within the pale of its protection. By disregarding it, though with no thought of personal gain distinct from the general gain to the bank, a loss is incurred. Why should they not be held responsible for the loss? They have violated a law which was enacted to prevent them from taking an excessive risk, why should they not be held accountable for the disaster? Their conduct was not an error of judgment, not a mistake, but an open and wilful, though honest, defiance of the law, which has brought loss in its train. Surely it is proper to visit them with punishment for their deed.

Another illustration of the same kind is the lending to an individual of more than a prescribed part of the bank's capital. The law was wisely designed, no one has the temerity to say it ought to

${ }^{1}$ Wallace v. Lincoln Sav. Bank, 80 Tenn. 630; Scott v. Depeyster, I Edw. Ch. (N. Y.) 513; Spering's Appeal, 7I Pa. II; Wetters v. Sowles, 3I Fed. I.

2.Vance v. Phoenix Ins. Co., 4 Lea (Tenn.) 385; Hodges v. New England Screw Co., I R. I. 312; Godbold v. Branch Bank, II Ala. IgI; Harman v. Tappenden, I East (Eng.) 535. But see Marshall v. Farmers \& Mechanics' Sav. Bank, 85 Va. 676, 683. 
be changed; it was adopted in the interest of sound conservative banking, to protect directors from yielding to the importunities of their friends and from giving too free rein to their own judgment. Surely if they violate it and losses follow, it is proper to hold them responsible for the violation. ${ }^{1}$

In the construction of violations of positive laws the courts have again parted company over the question of intention or motive. If the violation was intentional and premeditated, then all the courts unite in holding the violators guilty; but if they did not seriously consider the consequences of misdoing, acted blindly or indifferently or without much thought of what they were doing, some tribunals have overlooked their misdoing, notwithstanding that ancient and salutary rule whereby every man is supposed to regard the consequences of his own acts. If the courts themselves have too often ignored its application in dealing with offenders of the common law, there is less excuse for disregarding its application to offenders of plain, sound, living statutes.

Illustrations of this rule are the sale of a special deposit; ${ }^{2}$ the payment of dividends out of capital $;^{2}$ the making of investments or loans prohibited by law $; i^{4}$ the discounting of paper which is known to be worthless;." beginning business without the legal amount of capital $; ;^{\circ}$ accepting unauthorized securities in payment of stock $;^{7}$ creating an indebtedness beyond the capital stock $;^{8}$ or beyond a prescribed amount $;{ }^{9}$ or the payment of an illegal tax. ${ }^{10}$

Two other classes of specific violations require further consideration. One of these is the receiving of deposits by directors

'Witters v. Sowles, 3 I Fed. I; Witters v. Sowles, 43 Fed. 405; Stephens v. Overstolz, 43 Fed. 465 .

2United Society of Shakers v. Underwood, 9 Bush (Ky.) 609.

${ }^{3}$ Solomon v. Bates, II8 N. C. 3 II ; Gaffney v. Colvill, 6 Hill (N. Y.) 568 ; United States v. Britton, I08 U. S. 199, 206; Hayden v. Thompson, 36 U. S. App. 36r. See Houston v. Thornton, 122 N. C. 365.

4 Dodd v. Wilkinson, 42 N. J. Eq. affg. id. 234. See Wilkinson v. Dodd, 40 N. J. Eq. I23 and $4 \mathrm{I}$ N. J. Eq. 566; Williams v. McKay, 46 N. J. Eq. 25; Joint Stock Co. v. Brown, 8 Eq. Cases 381; Dunn v. Kyle, 14 Bush (Ky.) 134; Cooper v. Hill, 36 C. C. A. 402.

ifSavings Bank v. Caperton, $87 \mathrm{Ky} .306,322$.

'Schley v. Dixon, 24 Ga. 273; Trust Co. v. Floyd, 47 Ohio St. 525.

TMoses v. Ocoee Bank, I Lea (Tenn.) 398.

${ }^{8}$ Stone v. Chisolm, 113 U. S. 302 ; Hornor v. Henning, 93 U. S. 228 ; Brannin v. Loving, $82 \mathrm{Ky}$. 370 .

9. White v. How, 3 McLean (Fed.) II ; Hargroves v. Chambers, $30 \mathrm{Ga}$. 580; Banks v. Darden, $18 \mathrm{Ga}$. 318 .

10 Dodge v. Woolsey, I8 How. (U. S.) 331. 
when their bank is in an insolvent condition ${ }^{1}$ To hold directors liable for this act they must have actual as distinguished from constructive knowledge. ${ }^{2} \quad$ But when their lack of knowledge is the consequence of disregarding their duties then it furnishes no defence.

The other class of specific violations are false reports or statements by which others are misled and injured. In these cases the injured creditor may maintain an action for deceit against the directors who made them. The two classes of cases in which such actions have been most brought are by depositors ${ }^{3}$ and purchasers of stock. Furthermore a director, even though not participating in the fraud by signing the statement, is not, in all cases, relieved. ${ }^{5}$

Again, this remedy is not affected by the creation of another by statute. The latter is simply cumulative and not destructive of the other. ${ }^{8}$

Lastly the law will not permit a single creditor to appropriate the entire liability of the directors for such a fraud to his exclusive benefit. ${ }^{\top}$

X. A fourth class of cases may be cut off, those relating to the wrongful or neglectful exercise of authority. This may spring

${ }^{1}$ Cassidy v. Uhiman, I70 N. Y. 505; Cragie v. Hadley, 99 N. Y. I31; Anonymous, 67 N. Y. 598; Chaffee v. Fort, 2 Lans. (N. Y.) 8I; Townsend v. Williams, II7 N. C. 330; Tate v. Bates, 118 N. C. 287; Delano v. Case, I2r Ill. 247; Wolf v. Simmons, 75 Miss. 539, $54 \mathrm{I}$.

${ }^{2}$ Quin v. Earle, 95 Fed. 728; Perth Amboy Gas Light Co. v. Middlesex Co. Bank, 60 N. J. Eq. 84; Stapleton v Odell, 2I N. Y. Misc. 94; Utley v. Hill, I55 Mo. 232; State v. Tomblin, 57 Kan. 841; Minton v. Stahlman, 96 Tenn. 98 .

'Killen v. Barnes, I06 Wis. 546; Seale v. Baker, 70 Texas 286; Kinkler v. Junica, 84 Texas 116; Tate v. Bates, I18 N. C. 287; Solomon v. Bates, II8 N. C. 3 II ; Cowley v. Smith, 46 N. J. Law 380; Stuart v. Bank, 57 N. Y. 569; Prescott v. Haughey, 65 Fed. 653; Gerner v. Mosher, 58 Neb. I35. See Cowley case (supra) for mode of pleading in such actions.

${ }^{4}$ Cazeaux v. Mali, 25 Barb. 578; Cross v. Sackett, 2 Bos. (N. Y.) 6r7; Morgan v. Skiddy, 62 N. Y. 325; Houston v. Thornton, 122 N. C. 365 ; Gerner v. Mosher, 58 Neb. 135, reviewing many cases. Hubbard v. Weare, 79 Iowa 678; Salmon v. Richardson, 30 Conn. 360; Prewett v. Trimble, 92 Ky. 176; United States v. Allen, ro Biss. (Fed.) 90; Graves v. Lebanon Nat. Bank, ro Bush (Ky.) 23; Merchants Nat. Bank v. Thoms, 28 Ohio Week. Law Bull. I64, citing many cases.

${ }^{5}$ Gerner v. Mosher, 58 Neb. 135, 145, 160; Gerner v. Yates, 61 Neb. 100.

But see Pier v. Hanmore, 86 N. Y. 95.

${ }^{6}$ Stuart v. Bank, 57 Neb. 569; Prescott v. Haughey, 65 Fed. 653;

Houston v. Thornton, 122 N. C. 365. But see Utley v. Hill, I55 Mo. 232.

${ }^{7}$ Bailey v. Mosher, II C. C. A. 304, 307. 
from statute, or the common law, or both. If directors possess it, they are justified in exercising it; if not the possessors, they are as clearly guilty of usurpation, save in those cases in which they honestly suppose, and with some reason, that in exercising it, they are within the law. ${ }^{1}$ On the other hand, when directors are required to perform a specific duty, they cannot delegate its performance to others without incurring liability. Thus, in many States directors are justified in delegating their authority to lend the bank's money to the managing officers $;^{2}$ in other States they must still continue to perform this duty themselves." Where the inhibition prevails, they are as clearly guilty of negligence in not performing this duty as in not signing reports, holding meetings or fulfilling other positive requirements of the law.

Suppose a duty is rightfully delegated by the board to a managing officer, and he in performing it violates the statute, are the directors liable? Thus, a cashier was rightfully authorized to make loans, but in exercising this authority he violated the law forbidding his bank from lending more than one-tenth of its capital to a borrower. The directors were held not liable for the cashier's deliberate violation of the law." Though this decision may be free from criticism, I do not think the principle can be founded thereon that in all cases in which directors can rightfully authorize a

1"The directors cannot divest themselves of the duty of general supervision and control by committing this duty to [the cashier], but they properly may intrust to him all the discretionary powers which usually appertain to the immediate management of its business." Wallace, $\mathrm{Ch}$. J., Warner v. Penoyer, 33 C. C. A. 222, 226.

In the Penoyer case the board confided to a finance committee the duty of lending the bank's money, who, in turn, sought to relieve themselves from duty by confiding it wholly to the cashier who, in due time, wrecked the bank. The court decided not to hold the board for delegating their duty to the finance committee, but held the members of that committee responsible for delegating their duty to the cashier. The court remarked that the board was justified in supposing that the committee would attend to these duties instead of shirking them and leaving all to a single officer.

2In Warner v. Penoyer, 33 C. C. A. 222, 225, the court said: "The directors of a national banking association are authorized to appoint a cashier and delegate to him all the usual powers of such an officer, including the discounting of notes." Land Credit Co. v. Lord Fermoy, 5 Ch. App. 763.

${ }^{3}$ Union Nat. Bank v. Hill. 148 Mo. 380; Gibbons v. Anderson, 80 Fed. 345; Wallace v. Lincoln Sav. Bank, 89 Tenn. 630; Percy v. Millaudon, 3 La. 568; Wilkinson v. Dodd, 42 N. J. Eq. 234, 250, affd. id. 647; Houston v. Thornton. 122 N. C. 365 ; Oakland Bank v. Wilcox, 6o Cal. I26.

${ }^{1}$ Clews v. Bardon, 36 Fed. 617. 
managing officer to make loans they are not responsible for his conduct. They still have a supervisory power to perform, it is the duty of the managing officer to report the loans he has made to them and thus they know, or ought to know, what he is doing. There is therefore clearly a limit to the principle of the non-liability of directors for infractions of positive law by those whom they have appointed to manage the business of their bank. Surely they ought to be held for the violations that were known, or would have been known, had they attended to their duties. ${ }^{2}$ The rule, therefore, in this class of cases is, directors are liable for violating the statutes, and also for violations by those under their authority when they knew or ought to have known what they were doing. ${ }^{2}$

$\mathrm{XI}$. In applying the rules of duty and liability in the cases described not much difficulty has arisen. When fraud has existed, it has generally been discovered and punished. When directors have erred in employing officers or in making loans, or mistaken the law, the courts have not been greatly troubled in learning the truth. When directors have violated the statutes, whatever their intention, in most cases the violations were too plain to be ignored. Appointed to execute the law, the courts have not hesitated to enforce a plain command.

XII. The four classes of cases above mentioned may be considered from another point of view. Though everywhere regarded as cases of negligence, they possess another character. When committing frauds directors are just the opposite from negligent; they are too active. Indeed, the cases of real negligence do not relate to frauds, to violations of law, to usurpations of authority, but rather to the mode or manner of exercising authority. Negligence among bank directors is, in truth, chiefly neglect-neglect to do the things required of them, or to do them in a proper manner.

XIII. Eliminating all questions of fraud, mistake and specific violations of law, the cases that cover the remaining central ground are not so numerous perhaps as many imagine. It is easy enough to put them into classes relating to loans, ${ }^{3}$ employment of officers ${ }^{4}$ examination of books, and the like, but nothing would be gained

Gibbons v. Anderson, 80 Fed. 345 .

2In Brannin v. Loving, $82 \mathrm{Ky}$. 370 , the directors did not know that the president had violated the law.

Ky. 370

${ }^{3}$ Percy v. Millaudon, 8 Martin (La., N. S.) 68; Brannin v. Loving, 82

United Society of Shakers v. Underwood, 9 Bush (Ky.) 609.

'Directors are not liable for not detecting fraudulent entries made by their cashier in the bank books extending through a period of nine years. Savings Bank v. Caperton, 87 Ky. 306. 
by presenting such a classification. The same inquiry runs through them all; how, or in what manner was the authority of the directors exercised? Were they negligent or not in making the loan, in employing the officer, in retaining him after learning of his unfitness, in not examining the books more frequentiy, or more thoroughly? As this inquiry is first, one of fact; and afterward, the application of the rule of duty thereto,-the answer in one case is not conclusive in another; for the facts are never quite the same.

Nevertheless, we may inquire, cannot a general rule of duty be formulated to apply to directors, and not leave them entirely to the judgment of the court in each particular case? A negative conclusion has been declared by the Supreme Court of the United States. If a director is guilty of fraud, or of violating a statute, or of executing his authority, he is clearly liable. Beyond this he may be liable for something more, but precisely what cannot be told until the matter comes before the court for determination.

It is true that this was another five to four decision, and the minority, unwilling to confess their inability to prescribe a rule of conduct for directors, declared that "as to the degree of diligence and the extent of supervision to be exercised by directors, there can be no room for doubt under the authorities. It is such diligence and supervision as the situation and the nature of the business requires. Their duty is to watch over and guard the interests committed to them. In fidelity to their oaths, and to the obligations they assume, they must do all that reasonably prudent and careful men ought to do for the protection of others intrusted to their charge." 1

The Supreme Court of the United States is not the only tribunal maintaining this despairing opinion. In a recent case the Supreme Court of New Hampshire ${ }^{2}$ has declared that "the decisions in other jurisdictions, attempting to establish inflexible rules whereby it shall be settled that the existence of certain facts establishes a charge of negligence as a matter of law, are not entitled to the weight to which they would be if such views of the law prevailed in this State. The question of negligence, being here regarded as one of fact, is to be determined in the light of all the circumstances peculiar to the particular case." It was accordingly held that the directors of a bank were not liable for the defalcations of its cashier which

Briggs $v$ Spaulding, I4I U. S. 132,170 . In this case, the court declared that the directors must exercise supervision, but this was precisely what they did not do. yet by the majority were held not responsible.

${ }^{2}$ Ricker v. Hall, 69 N. H. 592. 
occurred after learning of his indulgence in prior unsuccessful speculations. Though the courts elsewhere, perhaps without exception, ${ }^{1}$ have held directors liable for the evil consequences attending the retention of a cashier or other officer after they knew he was speculating, the New Hampshire decision is a not unexpected deliverance for a court which is guided solely by its own light, regardless of the rules and reasonings of other tribunals.

The rule of duty and liability declared in Briggs v. Spaulding has been reluctantly followed by the lower federal courts in subsequent cases. The remarks on several occasions clearly reveal that their real opinion was quite different from that which they were required to adopt and apply. ${ }^{2}$ Remembering therefore that four of the nine judges who decided the case entertained a different view, that most of the federal judges in subsequent cases have followed it from necessity and not from conviction of its soundness, that with very few exceptions it has encountered the disapproval of the State tribunals, is it unreasonable to suppose that the question would receive the same answer should it ever be reviewed?

XIV. In the central zone, therefore, is left a class of cases of pure negligence. They are not tainted with fraud, they are not excusable mistakes, they are not violations either intentional or unintentional of any statutory requirement. They fall into two divisions. In the first are included the cases in which the negligence of directors, while stopping outside the door of fraud, is gross and without excuse. In the second class of cases, the negligence is not so great.

The negligent directors included in the second division are not regarded culpable by any courts; the directors included in the first division are regarded guilty by some courts, and not by others. With respect to these the courts are in hopeless conflict. Those which relieve directors apply either the first standard of duty and liability above described; or else determine each case, as was done by the supreme federal court in Briggs v. Spaulding, by itself. The

IIn Scott v. National Bank of Chester Valley, $72 \mathrm{~Pa} .47 \mathrm{I}, 480$, the court well said: "No officer in a bank, engaged in stock-gambling, can be safely trusted, and the evidence of this is found in the numerous defaulters, whose peculations have been discovered to be directly traceable to this species of gambling. * * * Any evidence of stock-gambling, or dangerous outside operations, should be visited with immediate dismissal." A similar view was taken in Preston v. Pratter, r37 U. S. 604. See Cutting v. Marlor, 78 N. Y. 454 .

2Warner v. Penoyer, 33 C. C. A. 222, 228; Mutual Building Fund \& Sav. Bank v. Bosseiux, 3 Fed. 817: Robinson v. Hall, 12 C. C. A. 674 . 
courts which condemn them apply the rule of liability laid down by Justice Earl. It may be added that the rule holding directors liable for gross negligence, even though untainted by fraud, commands wider assent and is believed to be more salutary in its operation.

Cases in which the maximum rule has been applied:

Alabama. Smith v. Prattville Mfg. Co., 29 Ala. 503.

Illinois. Delano v. Case, I7 Ill. App. affd., 121 I1l. 247.

Indiana. Coddington v. Canaday, 157 Ind. 243.

Kentucky. United Society of Shakers v. Underwood, 9 Bush 609; Jones v. Johnson, Io Bush 649; Ray v. Bank, Io Bush 344; Dunn v. Kyle, I4 Bush I34; Brannin v. Loving, $82 \mathrm{Ky}$. 370; Jones v. Johnson, $86 \mathrm{Ky} .530$; Savings Bank v. Caperton, $87 \mathrm{Ky} .306$.

Minnesota. Horn Silver Mining Co. v. Ryan, 42 Minn. 196, citing Hun v. Cary, 82 N. Y. 65.

Michigan. Commercial Bank v. Chatfield, r2I Mich. 64I.

Missouri. Union Nat. Bank v. Hill, 148 Mo. 380.

New Jersey. Ackerman v. Halsey, 37 N. J. Eq. 356; Dodd v. Wilkinson, 42 N. J. Eq. 647, affg. id. 234; Williams v. McKay, 46 N. J. Eq. 25, 56; Williams v. McKay, 40 N. J. Eq. 189, revsg. 38 N. Y. Eq. 373 .

New York. Cassidy v. Uhlman, 170 N. Y. 505; Hun v. Cary, 82 N. Y. 65 ; Bloom v. National Sav. \& Loan Co., 8I Hun I2I, I23.

Nebraska. Gerner v. Mosher, 58 Neb. I35.

North Carolina. Townsend v. Williams, II7 N. C. 330; Tate v. Bates, II 8 N. C. 287 ; Solomon v. Bates, II 8 N. C. 3 II.

Ohio. Meisse v. Loren, 6 Ohio Dec. 253.

Tennessee. Shea v. Mabry, I Lea 3I9, 342; Hume v. Commercial Bank, 9 Lea 728; Minton v. Stahlman, 96 Tenn. 98; Wallace v. Lincoln Sav. Bank, 89 Tenn. 630; Deadrick v. Bank, Ioo Tenn. 457,463 .

Texas. Seale v. Baker, 70 Texas 283 .

Virginia. Marshall v. Farmers \& Mechanics' Sav. Bank, 85 Va. 676.

Utah. Warren v. Robinson, 19 Utah 289.

Cases in which minor rule of liability was applied:

Louisiana. Percy v. Millaudon, 8 Martin (N. S.) 68.

Pennsylvania. Spering's Appeal, 71 Pa. II; Swentzel v. Penn Pank. I 47 Pa. I40: Maisch v. Saving Fund, 5 Phila. 30.

Wisconsin. Killen v. Barnes, 106 Wis. 546, 574; North Hudson Building \& Loan Asso. v. Childs, 82 Wis. 460.

Federal. Briggs v. Spaulding, I4I U. S. I32. 
XV. There is another phase of the subject worthy of notice, the narrowing of the responsibility of directors by reason of the extension. of the authority of managing officers. Of late years, in the large cities especially, the lending of a bank's money has been almost wholly done by a committee, or more often by the president or by two or three officers. The quicker methods of modern business demand this change. In imposing this most important duty on the managing officer, the directors in almost every State have the sanetion of law. Formerly this was the paramount duty of directors. In this direction, therefore, to the extent that their duty has been legally lightened, their corresponding liability has disappeared. ${ }^{*}$ But directors cannot relieve themselves entirely from responsibility by thus delegating their duties to a manager or committee. When they are charged with specific duties, these, as we have seen, must be performed. They are personal and cannot be transferred. How far they can go depends on the statute or charter which is the basis of the bank's existence and authority.

XVI. Lastly may be considered the question, what judgment may be visited on absent directors? If one is ill his non-attendance is excused; furthermore, a bank may give a leave of absence to a director who is sick, even though he be the president, expecting or hoping that he will recover and resume his duties. Not infrequently directors are elected for the purpose of strengthening the bank, gaining business, who live far away and are not expected to aid their associates by their presence and advice, or only on rare occasions. But we are now approaching dangerous ground. For, if all were excused because they were too busy to attend, the direction of the bank would pass entirely to the president, or a few of the leading officers. It is not proper for the directors to confide entirely the direction of their bank to its managers, however competent and worthy of confidence they may be, but to what extent attendance is a positive duty that cannot be neglected without rendering the absentee liable for the ill consequences is an open question and perhaps must always remain open for special answer. ${ }^{2}$

'See Warner v. Penoyer, 33 C. C. A. 222, 225.

2Briggs v. Spaulding, I4I U. S. 132. See North Hudson Building \& Loan Asso. v. Childs, 82 Wis. 460,478 , and Wheeler v. Aiken Co. Loan \& Sav. Bank, 75 Fed. 781, 782.

In Warren v. Robinson, ig Utah 289, Bartch, Ch. J., says: "A director is not responsible for acts committed, transactions made, or losses incurred before he became a member of the board, or for any act of the board alone in his absence and without his knowledge and assent." This is the English 
XVII. The wrongs of directors are primarily done to their bank, which can sue them in an action at law for their misdoing. ${ }^{2}$ But it often happens that the bank is in complete possession of the directors who are unwilling to proceed against themselves. Indeed, it can hardly be expected that they will transform themselves from mismanagers into reformers and prosecutors. But, if unwilling, the stockholders have a standing in a court of equity to sue in their own names making the bank a party defendant. ${ }^{2}$

XVIII. Too often the mismanagement of directors ends in the failure of their bank, and then the assignee or receiver succeeds to

rule. In re Cardiff Savings Bank, 2 Ch. Div. Ior; In re Denham \& Co., 25 Ch. Div. 752. See also Land Credit Co. v. Lord Fermoy, 5 Ch. App. 763. In Banks v. Dardon, $18 \mathrm{Ga}$. 3I8, absence and dissent when present did not relieve the directors. And in the recent case of Houston v. Thornton, I22 N. C. 365,373 , the Supreme Court of North Carolina said: "There is no principle of law or morals that will permit the selection of non-resident directors of good character, whose names shall be a pledge of honest management upon which the public shall make deposits and buy the stock of the bank, and then when the crush comes will excuse such directors from liability because, being non-residents, they could not give proper attention to their duties, and by private arrangement it was agreed that they should not be required to do so. Such arrangement, if it had been shown, would not have released them from their duties as prescribed by Act of Congress, nor from their common law liability for negligence or fraud."

Directors who are elected but do not accept are not liable. Maisch v. Saving Fund. 5 Phila. 30; Hume v. Commercial Bank, 9 Lea (Tenn.) 728.

${ }^{1}$ Hun v. Cary, 82 N. Y. 65; Bloom v. National Sav. \& Loan Co., 8I Hun 120; O’Brien v. Fitzgerald, I43 N. Y. 374; Meisse v. Loran, 6 Ohio N. P. 307; Ackerman v. Halsey, 37 N. J. Eq. 356; Conway v. Halsey, 44 N. J. Law 462 ; Horn Silver Mining Co. v. Ryan, 42 Minn. 196; National Bank v. Wade, 84 Fed. 10.

${ }^{2}$ Greaves v. Gonge, 69 N. Y. 155; Robinson v. Smith, 3 Paige (N. Y.) 222: Morgan v. King, 27 Colo. 539; Smith v. Dorn, 96 Cal. 73; Higgins v. Lansingh, 154 Ill. 301 ; Knoop v. Bohmrich, 23 Att. II8; Craig v. Craig, 83 Pa. 19.

"The liability of the directors of corporations for violations of their duty or breach of the trust committed to them, and the jurisdiction of courts of equity to afford redress to the corporation, and in proper cases to its shareholders, for such wrongs, exist independently of any statute. * * * This jurisdiction has been continually exercised in England and in this country and is not of statutory origin." Rapallo, J., Brinckerhoff v. Bostwick. 88 N. Y. 52. 58, 59. 
all its rights and liabilities and he may proceed against the directors. In a large number of cases he has been the suing party.

XIX. If bank is insolvent and the assignee or receiver declines to sue the directors, then all the stockholders, or one or more in behalf of all can proceed in equity against them. ${ }^{2}$

$\mathrm{XX}$. In many cases the creditors proceed against the directors. Once this could not be done because no legal relation of any kind was recognized as existing between them. ${ }^{3}$ The claims of creditors were against the bank, and the bank only could proceed against the directors for their misdeeds. The fact that the damages recovered by the bank of the directors would go immediately to its creditors did not justify the latter, so the courts once thought, in their attempt to recover directly from the directors themselves. And this view is still maintained by some tribunals." But the more gen-

1Thompson v. Greeley, I07 Mo. 577; Union Nat. Bank v. Hill, I48 Mo. 380, 393; Hun v. Cary, 82 N. Y. 70; Brinckerhofi v. Bostwick, 88 N. Y. 52; O'Brien v. Fitzgerald, I43 N. Y. 377; Higgins v. Tefft, 4 N. Y. App. Div. 62; Dykman v. Keeney, 21 N. Y. App. Div. II4; Robinson v. Smith, 3 Paige (N. Y.) 230; Hume v. Commercial Bank, 9 Lea (Tenn.) 744; Wallace v. Lincoln Sav. Bank, 39 Tenn. 630, 637; Savings Bank v. Caperton, 87 Ky. 306; Jones v. Johnson, 86 Ky. 530; Williams v. Halliard, 34 N. J. Eq. 34I; Gibbons v. Anderson, 80 Fed. 345.

${ }^{2}$ Brinckerhoff v. Bostwick, 88 N. Y. 52; Greaves v. Gouge, 69 N. Y. 154; Sayles v. White, 18 N. Y. Div. 590; Robinson v. Smith, 3 Paige (N. Y.) 230; Jones v. Johnson, to Bush (Ky.) 649 ; Hickens v. Congreve, 4 Russ. (Eng.) 574; Union Nat. Bank v. Hill, I48 Mo. 380, 394.

'Zinn v. Mendel, 9 W. Va. 580; Smith v. Hurd, I2 Met. (Mass.) $37 \mathrm{I}$;. Smith v. Poor, 40 Me. 415; Allen v. Curtis, 26 Conn. 456; Landis v. Sea Isle City Hotel Co., 31 Atl. (N. J.). This case contains the fullest consideration of the rule of any modern case. See opinion of Court of Errors, affirming the Vice Chancellor, 53 N. J. Eq. 654; Savings Bank v. Caperton, $87 \mathrm{Ky}$. 306; Jones v. Johnson, ro Bush (Ky.) 649; Winter v. Baker, 34 How. Pr. 183; Gardner v. Pollard, Io Bos. (N. Y.) 674; Abbott v. Merriam, 8 Cush. (Mass.) 588; Conway v. Halsey, 44 N. J. Law 462.

'Savings Bank v. Caperton, $87 \mathrm{Ky} .306,323$. In this case the court remarked that the directors were under no personal liability to the creditors of a bank by reason of a neglect of duty; that they were the agents of the corporation and could be sued by the creditors only because of the assignee's refusal. But when "the directors are the parties to be charged there is no reason why the creditor may not sue, making the bank and the directors the defendant in this case for a neglect of duty."

Bank of St. Mary's v. St. John, 25 Ala. 566. This is one of the earlier American cases and the court held that the creditors of the bank, which was insolvent, could proceed in equity against the directors without first obtaining a judgment at law for the amount of their debt.

Solomon v. Bates, II8 N. C. 3II, 320; Ackerman v. Halsey, 37 N. J. Eq. 356 ; Meisse v. Loren, 5 Ohio N. P. 307, 309; Gager v. Paul, III Wis. 638;
Killen v. Barnes, I06 Wis. 546. 
eral rule is in cases where neither the bank, nor its assignee or receiver, nor its stockholders can or will proceed at all, or to less advantage than the creditors, they are not denied a remedy against the directors. In thus acting, though the fruits of their action are to be wholly or in part retained by themselves, they act as a substitutionary party for the bank, or its assignee, receiver or stockholders. Regarding this as the correct view, the objection that creditors cannot proceed against the directors because the former are in no sense the trustees of the latter, disappears. It is an objection raised to a shadow which would have never troubled the judicial mind had it looked at the true relations of the parties.

On another ground the creditors' right to proceed against the directors is not less secure to them. The liability of the directors is a trust fund belonging to the bank which the creditors have a right to follow and apply in discharge of its indebtedness to themselves.

The only question pertaining to the remedial rights of creditors is that of precedence over the receiver, assignee or stockholder. In practice, there has been but little difficulty, for as the object of the proceeding in any case is to obtain the means to satisfy creditors, they are quite willing for other parties to enforce measures against the directors to compel them to respond instead of introducing and enforcing measures themselves.

With this conception of the proceedings undertaken by creditors against directors, the distinction between the rule of duty and liability of directors to the bank and to its creditors, stated at the beginning of this inquiry, crumbles away.

Albert S. Bolles. 